\title{
EKSEKUSI GROSSE AKTA MERUJUK PADA PASAL 244 HIR DAN PUTUSAN MAHKAMAH AGUNG
}

\author{
Mochammad Taufiq Arifin \\ Magister Kenotariatan \\ Program Pascasarjana Universitas Islam Malang \\ Jl. Mayjen Haryono No.193 Malang \\ Email :mtaufiqarifin@gmail.com
}

\begin{abstract}
Abstrak
Dalam sebuah grosse akta akan memiliki kekuatan hukum eksekutorial apabila dalam pembuatan akta harus diperhatikan syarat- syaratnya, baik itu syarat formil maupun syarat materiil, serta grosse akta tersebut harus murni berdiri sendiri, yang artinya bahwa grosse akta tersebut tidak dicampur-aduk dengan perjanjian lainnya..Bahwa grosse akta harus terlebih dahulu meminta fiat putusan pengadilan negeri, bertujuan untuk menilai adanya cacat yuridis pada suatu akta tersebut atau tidak, dan apabila ada hakim dalam pemeriksaannya menemukan cacat yuridis dalam isi perjanjiannya maka grosse akta tersebut untuk pelaksanan eksekusinya harus melalui gugatan perdata biasa.
\end{abstract}

Kata kunci: akta, eksekusi, putusan, hakim

\section{Abstract}

In a grosse deed, it will have executorial legal power in making the deed, the conditions must be considered, both formal and material requirements. As well as the grosse deed must be purely independent, which means that the grosse deed is not mixed up with other agreements. That the grosse deed must first ask for a fiat court decision, aiming to assess whether there is a juridical defect on the deed or not and if there is a judge in his examination to find a juridical defect in the contents of the agreement, the grosse deed for execution must go through an ordinary civil suit.

Keywords: deed, execution, decision, judge

\section{PENDAHULUAN}

Undang-Undang Dasar Negara Republik Indonesia tahun 1945 menentukan secara tegas bahwa negara Republik Indonesia adalah negara hukum. Prinsip negara hukum menjamin kepastian, ketertiban, dan perlindungan hukum yang berintikan kebenaran dan keadilan.Kepastian, ketertiban, dan perlindungan hukum menuntut, antara lain, bahwa perjalanan hukum dalam kehidupan masyarakat memerlukanadanya alat bukti yang menentukan dengan jelas hak dan kewajiban seseorang sebagai 
subjek hukum dalam masyarakat. Akta autentik adalah suatu akta yang di dalam bentuk yang ditentukan oleh undang-undang, dibuat oleh atau dihadapan pegawai-pegawai umum yang berkuasa untuk itu di tempat di mana akta dibuatnya.

Dalam berbagai hubungan bisnis, kegiatan dibidang perbankan, pertanahan, kegiatan sosial, dan lain-lain, kebutuhan akanpembuktian tertulis berupa akta otentik makin meningkat sejalan dengan berkembangnya tuntutan akan kepastian hukum dalam berbagai hubungan ekonomi dan sosial, baik pada tingkat nasional, maupun global, melalui akta otentik yang menentukan secara jelas hak dan kewajiban, menjamin kepastian hukum, dan sekaligus diharapkan pula dapat dihindari terjadinya sengketa. Walaupun sengketa tersebut tidak dapat dihindari, dalam prosespenyelesaian sengketa tersebut, akta otentik yang merupakan alat bukti tertulis terkuat dan terpenuh memberi sumbangan nyata bagi penyelesaian perkara secara murah dan cepat.

Dalam kehidupan masyarakat perjanjian kredit sering pihak kreditur berada dalam posisi yang tidak diuntungkan ketika debiturlalai dalam melaksanakan prestasinya (wanprestasi) padahal utangnya telah melewati batas jatuh tempo pembayaran, hal ini disebabkan karena proses untuk mengambil pelunasan melalui penjualan objek jaminan tidak semudah seperti yang dibayangkan, apalagi jika debitur atau si pemilik jaminan tidak beritikad baik untuk menyelesaikan kewajibannya, maka akan selalu ada cara untuk dapat menghambat proses pelunasan dengan objek jaminan, baik dengan upaya-upaya yang disediakan menurut prosedur hukum acara perdata, maupun dengan cara-cara lain yang pada akhirnya dimaksudkan agar si kreditur gagal atau tidak berhasil mendapatkan pelunasan dengan objek jaminan miliknya.

Apabila diperhatikan baik-baik bunyi Pasal 224 HIR, bahwa surat asli dari pada surat hipotik dan surat utang, yang dibuat di hadapan notaris di Indonesia dan yang memakai perkataan: "atas nama keadilan" di kepalanya, kekuatannya sama dengan surat putusan hakim. Dalam hal menjalankan surat yang demikian, jika tidak dipenuhi dengan jalan damai, maka dapat diperlakukan peraturan pada bagian ini, akan tetapi dengan pengertian, bahwa paksa badan hanya boleh dilakukan sesudah diizinkan oleh putusan Hakim. Jika hal menjalankan putusan itu harus dijalankan sama sekali atau sebagian di luar daerah hukum pengadilan negeri, yang ketuanya memerintahkan menjalankan itu, maka peraturan-peraturan pada pasal 195 ayat kedua dan yang berikutnya dituruti.

Pada kenyataannya, sejak dekade 1980-an pengadilan di Indonesia mengambil sikap berbeda. Antara lain bisa ditelusuri dari surat-surat yang pada waktu itu dikeluarkan oleh Ketua Muda Perdata Tertulis Asikin 
Kusumah Atmadja (Catatan No. VII/1988/Perdata, Pebruari 1988 yang diselipkan di bawah Putusan No. 1520K/Pdt/1984, 31 Mei 1986). Terlepas dari pendapat yang dikutip secara salah dari sebuah putusan dalam bahasa Belanda yang sebenarnya memuat penyataan yang berarti keberatan (perlawanan) terhadap pelaksanaan eksekusi (grosse akta tersebut) tunduk pada putusan hakim, alasan pengadilan sebenarnya cukup berdasar. Pada kesempatan lain. Asikin kembali menegaskan bahwa "dapat dilaksanakannya atau tidak suatu eksekusi atas suatu akta grosse seperti yang dimaksudkan oleh Pasal 224 HIR merupakan wewenang sepenuhnya dari hakim yang bersangkutan. Pendapat ini secara umum diikuti oleh pengadilan, sehingga pada akhirnya eksekusi mengenai grosse akta yang sebenarnya telah ditentukan oleh peraturan perundang-undangan pada prakteknya tidak berjalan efektif.

Irah-irah ini, dalam perkembangan hukum di Indonesia cukup penting karena menyangkut landasan mendasar hukum, yaitu legitimasi. Pada tahun 1955, Pemerintah Daerah Istimewa Yogyakarta (DIY) bahkan secara resmi mengganti irah-irahnya dari berbahasa Jawa "Penget trang dawuh timbalan Dalem Sampeyan Dalem Hingkang Sinuwun Kangjeng Sultan ing Ngayogyakarta" (Peringatkanlah atas Perintah dari Sri Paduka Kangjeng Sultan Yogyakarta) menjadi "Atas Nama Keadilan" untuk menyesuaikan dengan irah-irah yang digunakan dalam putusan-putusan pengadilan yang berlaku di Republik Indonesia ketika itu ( Perda DIY No. 1/1955 tentang Perubahan Salinan Pertama (Grosse) Credietverband). Irahirah "Atas Nama Keadilan" sendiri pada tahun 50-an sempat memenangkan persaingan dengan irah-irah "Atas Nama Negara Republik Indonesia", dengan merujuk pada format putusan Mahkamah Agung, sebelum pada tahun 1970 ditetapkan berbunyi "Demi Keadilan Berdasarkan Ketuhanan Yang Maha Esa" (Dari permasalahan yang digambarkan di ataspenulis memilih topik grosse akta dikarenakan terdapatnya kesimpangsiuran terkait grosse akta yang mempunyai judul "Demi Keadilan Berdasarkan Ketuhanan Yang Maha Esa" seperti irah-irah putusan pengadilan yang mempunyai kekuatan eksekutorial, namun masih banyak ditemui dalam putusan pengadilan bahwa suatu grosse akta masih harus diajukan ke pengadilan untuk eksekusinya. Kesimpangsiuran seperti ini penting untuk dikaji lebih mendalam.

\section{METODE PENELITIAN}

Riset yang ditulis dalam karya ini, berangkat dari suatu metode penelitian yang tepat, karena metode penelitian sangat penting dalam penulisan karya ilmiah sebagai pedoman dalam pelaksanaan analisa terhadap data dari penelitian untuk menghasilkan jawaban-jawaban atas 
permasalahan yang dibahas. Setiap penulisan karya ilmiah tentunya menggunakan cara tertentu, hal ini sudah merupakan suatu ciri dari karya ilmiah yang mengandung kebenaran, dimana kebenaran tersebut dapat dibuktikan dengan adanya data atau obyek (bahan), sehingga menunjukkan sifat ilmiahnya ${ }^{1}$

Jenis penelitian yang digunakan dalam penelitianini adalah yuridis normatif . Menurut Soerjono Soekanto penelitian yuridis normatif adalah penelitian hukum yang dilakukan dengan cara meneliti bahan pustaka atau data sekunder sebagai bahan dasar untuk diteliti dengan cara mengadakan penelusuran terhadap peraturan-peraturan dan literatur-literatur yang berkaitan dengan permasalahan yang diteliti. ${ }^{2}$ Bahan hukum dalam penelitian ini menggunakan bahan hukum primer, sekunder, dan tersier. Teknik pengumpulan bahan hukumnya menggunakan teknik dokumentasi. Adapun analisis bahan hukumnya menggunakan analisis isi (content analisys).

\section{PEMBAHASAN}

\section{Grosse Akta Memiliki Kekuatan Hukum Eksekutorial}

Tidaklah semua surat dapat disebut suatu akta, melainkan hanya surat-surat tertentu yang memenuhi syarat-syarat tertentu pula baru disebut akta. Adapun syarat-syarat tersebut antara lain surat itu harus ditandatangani, memuat peristiwa yang menjadi dasar sesuatu hak atau perikatan, dan diperuntukkan sebagai alat bukti. Berdasarkan Pasal 1867 KUH Perdata "pembuktian dengan tulisan dilakukan dengan tulisan (akta) autenti maupun dengan tulisan (akta dibawah tangan)". Diantara kedua akta tersebut memiliki kekuatan pembuktian yang berbeda. Apabila berbicara tentang grosse akta, tentunya kita tidak akan terlepas dari akta notaris itu sendiri, sebab suatu grosse itu tidak lain adalah merupakan suatu salinan atau turunan akta notaris yang diberi titel eksekutorial, yang artinya memiliki sifat dan karakteristik yang khusus, yang berbeda dengan akta notaris lain, sebab selain merupakan alat bukti sempurna bagi para pihak juga memiliki kekuatan eksekutorial.

Berdasarkan Surat Edaran Mahkamah Agung Nomor 213/229/85/Um-TU/Pdt menjelaskan pengertian grosse akta seperti yang dimaksud pasal $224 \mathrm{HIR}$ atau $258 \mathrm{RBg}$ adalah suatu akta autentik yang berisi pengakuan hutang dengan perumusan semata-mata suatu kewajiban untuk membayar/melunaskan sejumlah uang tertentu. Hal ini berarti dalam

${ }^{1}$ Hilman Hadikusumo, Metode Pembuatan Kertas Kerja / Skripsi Ilmu Hukum, (Bandung: Mandar Maju, 1995), hal.58

${ }^{2}$ Soerjono Sokanto dan Sri Mamjudji, Penelitian Hukum NOrmatf (Suatu Tinjauan Singkat), (Jakarta. Rajawali Press, 2001), hal.13-14 
suatu grosse akta tidak dapat ditambahkan persyaratan-persyaratan tersebut berbentuk perjanjian. ${ }^{3}$

Dalam Pasal 55 ayat (3) UUJN telah disebutkan bahwa suatu Grosse Aktapengakuan hutang pada bagian kepala akta memuat frasa "diberikan sebagai grosse pertama", dengan menyebutkan nama orang yang memintanya dan untuk siapa grosse dikeluarkan serta tanggal pengeluarannya. Namun didalam praktek sering terjadi ketidakseragaman penerapan tentang sahnya grosse akta pengakuan hutang berdasarkan pasal 224 HIR, disebutkan tidak adanya kesepakatan pendapat mengenai standar hukum. Persyaratan yang merupakan Unified legal framework mengenai grosse pengakuan hutang, yaitu: ${ }^{4}$

a. Syarat formil

1) Berbentuk akta notaris

a) Bisa merupakan lanjutan atau peningkatan dari perjanjian hutang semula (dokumen pertama);

b) Bisa juga perjanjian hutang langsung dituangkan dalam bentuk akta notaris.

2) Memuat titel eksekutorial

a) Lembar minut (asli) disimpan oleh notaris;

b) Grosse (salinan yang memakai irah-irah) diberikan kepada kreditur.

Harus diingat tidak ada kewajiban hukum memberikan grosse kepada debitur, karenanya tidak diberikan kepada debitur tidak melanggar syarat formal dan tidak menghalangi parate eksekusi

b. Syarat materiil

1) Memuat rumusan pernyataan sepihak dari debitur

a) Pengakuan berhutang kepada kreditur;

b) Dan mengaku wajib membayar pada waktu yang ditentukan;

c) Dengan demikian rumusan akta tidak boleh memuat ketentuan perjanjian atau tidak boleh dimasukan dan dicampurkan dengan perjanjian hipotik.

2) Jumlah hutang sudah pasti (fixed loan) tidak boleh berupa kredit plafon

a) Jadi jumlah hutang pasti dan tertentu;

${ }^{3}$ Martias Gelar Imam Radjo, Pembahasan Hukum; Penjelasan Istilah Hukum Belanda. (Jakarta: Ghalia Indonesia. 1987), hal. 34.

${ }^{4}$ M. Yahya Harahap, kedudukan Grosse Akta Dalam Perkembangan Hukum di Indonesia. (Jakarta: Media Notariat. 1988), hal. 34. 
b) Berarti pada saat grosse akta dibuat, jumlah hutang sudah direalisir;

c) Jangkauan hutang yang pasti meliputi hutang pokok ditambah bunga (ganti rugi).

Selain itu, dalam setiap grosse akta pengakuan hutang harus memenuhi asas sepasialitas dalam arti: ${ }^{5}$

a. Harus menegaskan barang agunan hutang tanpa menyebutkan barang agunan dianggap tidak memenuhi syarat, dengan demikian grosse akta tersebut jatuh menjadi ikatan hutang biasa dan pemenuhannya tidak dapat melalui pasal $224 \mathrm{HIR}$, tapi harus melalui gugatan biasa.

b. Agunanya harus barang tertentu bisa berupa barang bergerak maupun tidak bergerak.

c. Grosse akta pengakuan hutang yang dapat dieksekusi berdasarkan pasal $224 \mathrm{HIR}$, hanya barang agunan saja sesuai dengan spesialitas, sekiranya executorial verkoop atas barang aguanan tidak memnuhi perlunasan hutang, maka tidak boleh diahlikan terhadap orang lain dan kekurangannya itu harus dituntut melalui gugatan perdata biasa kepada Pengadilan Negeri.

Selain syarat formil dan materiil terdapat juga syarat berbentuk dan syarat isi dari Grosse Akta pengakuan hutang adalah: ${ }^{6}$

a. Kepala grosse akta Pengakuan Hutang. Pada bagian kepala membuat kata-kata: "Demi Keadilan Berdasarkan Ketuhanan Yang Maha Esa" (pasal 224 HIR jo Pasal 38 ayat 2 UUJN). Apabila pada bagian kepala grosse akta pengakuan hutang tidak mempunyai kekuatan eksekutorial. Bila Notaris lupa atau lalai mencantumkan kata-kata tersebut dalam kepala grosse akta pengakuan hutang maka Notaris akan dikenakan sanksi denda.

b. Nomor grosse akta pengkuan hutang. Nomor grosse akta pengakuan hutang sama dengan akta autentiknya. Walaupun tidak ada ketentuan dalam UUJN yang menerapkan sanksi bagi Notaris yang mencatumkan nomor pada setiap aktanya, namun dengan pemberian nomor pada setiap akta tentunya dapat membantu administrasi dan menguntungkan bagi notaris sendiri untuk arsipnya.

${ }^{5}$ M. Yahya Harahap. Perlawanan Terhadap Eksekusi Grosse Akta Serta Putusan Pengadilan dan Arbitrase dan Standar Hukum Eksekusi. (Bandung: Citra Aditya Bakti. 1993), hal. 71..

6 Nia Mardianto. "Peranan Grosse Akta Pengakuan Hutang dalam Eksekusi Jaminan Kredit Harta Kekayaan”. Program Studi Ilmu Hukum Universitas Pembangunan Nasional "Veteran" Jawa Timur. 2012, hal. 67. 
c. Judul akta. Dalam peraturan jabatan notaris tidak ada ketentuan notaris harus mencantumkan judul. Walaupun demikian apabila suatu akta dibuat tanpa judul tentunya akan membingungkan notaris dan para pihak yang memuat akta tersebut.

d. Awal akta grosse akta Pengakuan Hutang. Pada awal akta grosse akta pengakuan hutang harus dimuat hari dan tanggal dibuatnya akta, nama lengkap para pihak dan tempat kedudukan notaris serta sanksi-sanksi intrumentair. Apabila Notaris tidak memuat syarat ini maka notaris akan dikenakan denda atau akta notaris hanya sebagai akta dibawah tangan.

e. Komparisi. Komparisi adalah kewenangan menghadap dari masing-masing pihak di depan pejabat yang berwenang untuk bertindak hukum untuk mana akta tersebut dibuat.

f. Premis. Dalam peraturan jabatan notaris tidak ada ketentuan yang mengharuskan pemuatan premis dalam akta autentik. Pada bagian premis grosse akta pengakuan hutan dapat disebutkan perjanjian yang menjadi dasar dilakukannya utang. Bila dasar pengakuan hutang terdapat bunga atau denda maka perhitungan jumlah seluruh hutang dicantumkan pada bagian premis akta.

g. Isi grosse akta Pengakuan hutang

1) Pengakuan hutang sepihak oleh debitur.

2) Kewajiban membayar sejumlah uang tertentu.

3) Dalam jangka waktu tertentu.

4) Tempat pembayaran.

5) Opeisbaarheid (dapat ditagih)

\section{Permasalahan Dalam Pelaksanaan Eksekusi Grosse Akta Pengakuan Hutang}

Kaitannya dengan perjanjian kredit bahwa dalam praktek pemberian grosse akta tersebut merupakan alat bukti adanya hutang, adapun alasanalaan dibuatnya grosse akta adalah sebagai berikut: ${ }^{7}$

a. Perjanjian kredit tidak memiliki kekuatan eksekutorial sehingga debitur melakukan wanprestasimaka kreditur tidak dapat melakukan eksekusi langsung terhadap jaminan yang ada tetapi harus melakukan gugatan melalui Pengadilan Negeri terlebih dahulu.

b. Akta pengakuan hutang merupakan perjanjian sepihak, yang artinya didalamnya hanya memuat sebuah kewajiban untuk membayar hutang sejumlah uang tertentu. Akta pengakuan hutang yang dibuat dihadapan

${ }^{7}$ Febby M. Sukatendel. Panduan Bantuan Hukum di Indonesia:Pedoman anda Memahani dan Menyelesaikan Masalah Hukum (Kerdit dan Masalah Keuangan). Jakarta: YLBHI. 2009, hal. 90. 
Notaris berdasarkan Pasal 224 HIR dan 258 RBg memiliki kekuatan hukum yang sama seperti keputusan hakim, dengan kata lain dapat diartikan bahwa akta pengakuan hutang memiliki kekuatan eksekutorial.

c. Mempercepat proses eksekusi tanpa memerlukan gugatan terlebih dahulu kepada debitur.

Prakteknya masih banyak permasalahan yng menghambat jalannya eksekusi grosse akta pengakuan hutang yang diajukan kepada Pengadilan Negeri sehingga seringkali permohonan eksekusi telah memnuhi syarat formil, namun ditolak oleh Pengadilan Negeri berdaasarkan berbagai alasan, antara lain: ${ }^{8}$

a. Isinya tidak merupakan pengakuan hutang sepihak;

b. Jumlahnya tidak pasti karena dalam isi akta tersebut ditentukan bunga dan/atau denda;

c. Berdasarkan keberatan secara tertulis dari debitur terhadap eksekusi grosse akta dengan alasan:

1) Jumlahnya tidak pasti karena dari jumlah yang tertera pada grosse akta pengakuan hutang sebagian telah dibayar dengan menunjukan kuitansi tanda terima pembayaran dari kreditur pemohon eksekusi. Melihat kembali pengertian akta pengakuan hutang yang dimaksud dalam Pasal 224 HIR , maka haruslah menyatakan jumlah uang yang tertuang harus pasti dan secara langsung disebut dan ditentukan dalam grosse akta pengakuan hutang tersebut.

2) Meskipun judulnya grosse akta pengakuan hutang, isinya tidak sepihak karena dalam grosse akta tersebut dimasukkan perjanjian yang menjadi sumber hutang. Sehingga menurut Ketua Pengadilan Negeri grosse akta tersebut tidak memenuhi syarat materiil untuk dikabulkan karena isinya tidak berupa pengakuan hutang sepihak/murni.

Selain disebutkan diatas, permasalahan grosse akta pengakuan hutang adalah penafsiran yang berbeda-beda mengenai substansi dari Pasal 224 HIR dan 258 Rbg. Hal ini menyebabkan eksekusi menggunakan Grosse Akta pengakuan hutang tidak diterima oleh Pengadilan Negeri. Tidak terpenuhinya syarat formil maupun syarat materiil juga menyebabkan grosse akta tidak diterima oleh Pengadilan Negeri. Perlu diketahui oleh pihak-pihak yang berkepentingan baik debitur maupun kreditur, permohonan eksekusi grosse akta pengakuan hutang dapat tidak diterima ketikadilakukan aanmaning oleh Ketua Pengadilan Negeri, pada saat debitur

${ }^{8}$ Shendy Vianni Rangian. "Pelaksanaan Eksekusi Grosse Akta Pengakuan Hutang Dalam Penyelesaian Sengketa Kredit Macet Perbankan”. Jurnal Calyptra. Vol. 4 Nomor 1. Surabaya: Fakultas Magister Kenotariatan Universitas Surabaya. 2015, hal. 102. 
tidak mengakui jumlah hutang yang pasti, maka permohonan tidak dapat diterima dan kepada kreditur dimohon untuk mengajukan gugatan perdata biasa.

\section{Grosse Akta Harus Terlebih Dahulu Meminta Fiat Putusan Pengadilan}

Pengakuan hutang telah memberikan syarat-syarat tertentu yang didasarkan pada Pasal $258 \mathrm{Rbg} / 224 \mathrm{HIR}$. Yang merupakan syarat formal yang harus dipenuhi dalam suatu Grosse Akta pengakuan hutang yang berkekuatan eksekutornya. Namun selain syarat-syarat formal, ada juga syarat-syarat materialnya yang juga berdasar atas Pasal $224 \mathrm{HIR} / 258 \mathrm{Rbg}$ yaitu isi daripada grosse akta pengakuan hutang adalah benar-benar harus merupakan suatu pengakuan hutang yang berasal dari suatu perjanjian hutang piutang atau dengan kata lain bahwa terjadinya pengakuan hutang tersebut adanya perjanjian-perjanjian yang lain yang mendasarinya. ${ }^{9}$

Grosse akta pengakuan hutang tersebut harus berisi atau merupakan suatu pengakuan hutang sepihak. Pernyataan ini harus mengandung makna bahwa yang mengaku adanya hutang terhadap kreditur hanya pihak debitur saja (hanya satu pihak), sedangkan pihak kreditur tidak perlu ikut serta mengakui didalam grosse akta pengakuan hutang tersebut. Memang dalam praktek pelaksanaannya, banyak dalam grosse akta pengakuan hutang, yang dimohonkan eksekusinya di Pengadilan Negeri sebagian berisi pengakuan kedua belah pihak, yaitu debitur dan kreditur dan bahkan pihak penjamin juga masuk dalam grosse akta pengakuan hutang tersebut yang akhirnya terjadi pencampuradukan grosse akta. Oleh Pengadilan Negeri, grosse akta pengakuan hutang tersebut dianggap bukan lagi merupakan suatu pengakuan hutang murni sebab dalam hal ini ada beberapa pihak yang terdapat didalamnya dan juga ada beberapa klausul yang seharusnya tidak dimuat dalam grosse akta tersebut. Sehingga hal-hal inilah yang juga dapat menyebabkan grosse akta pengakuan hutang itu ditolak oleh Pengadilan Negeri Malang.

Dalam grosse akta pengakuan hutang juga harus dicantumkan secara jelas dan tegas tentang jumlah utang debitur kepada kreditur atau hutang itu harus ditentukan dan pasti, tidak boleh ditambah dengan persyaratanpersyaratan lain. Sehingga jumlah hutang dalam grosse akta pengakuan hutang tersebut dapat diketahui secara langsung dan mudah. Syarat lain yang harus dipenuhi adalah tentang bunga, ongkos notaris/ pengacara dan perjanjian lainnya tidak boleh disebut dalam grosse akta pengakuan hutang. Berkaitan dengan syarat keempat inilah yang ternyata didalam beberapa grosse akta pengakuan hutang hal-hal tersebut justru disebut didalam grosse

\footnotetext{
${ }^{9}$ Mariam Badrulzaman. Serial Hukum Perdata Kompilasi Hukum Jaminan, Buku
} II. (Jakarta: Mandar Maju: 2004), hal. 54. 
akta tersebut. Dalam hal ini juga yang merupakan kelemahan dari bentuk grosse akta yang bersangkutan.

Syarat material lainnya adalah harus disebutkannya jangka waktu pengembalian hutang, tempat pembayaran hutang dan hal-hal yang menyebabkan hutang dapat ditagih atau dibayar seketika. Menanggapi grosse akta pengakuan hutang yang ditolaak oleh Pengadilan Negeribahwa didalam Grosse Akta pengakuan hutang tersebut telah terjadi pencampuradukan. Pencampuradukan terjadi antara grosse akta pengakuan hutang, substansi grosse akta hipotik dan adanya pengakuan hutang dengan jaminan, yang didalam kesimpulannya bahwa grosse akta pengakuan hutang tersebut bukan grosse akta pengakuan hutang yang murni. Hal lain didalam grosse akta pengakuan hutang tersebut ada klausul-klausul tambahan yang bukan substansi dari grosse akta pengakuan hutang. Sementara itu yang dimaksud grosse akta pengakuan hutang adalah "pengakuan hutang murni". Artinya dari bentuk maupun substansinya tidak boleh ditambahkan dengan hal-hal lain.

\section{Akibat Hukum Pencampuradukan Grosse Akta Pengakuan Hutang}

Grosse Akta yang dianggap mengandung cacat yuridis, karena dengan sendirinya telah melenyapkan kepastian bentuk grosse akta, telah dibuat perjanjian kredit pokok yang dituangkan dalam bentuk grosse akta pengakuan hutang, tapi sekaligus didalam grosse akta pengakuan hutang tersebut masih dicantumkan syarat-syarat perjanjian dan kuasa memasang hipotik serta adanya pencantuman jaminan. Sehingga didalam grosse akta tersebut tidak ada kepastian hukum yang sebenarnya. Dilihat dari bentuknya tidak dapat dikatakan grosse akta pengakuan hutang, karena disamping rumusan substansi Pasal-Pasal aktanya mengandung pernyataan pengakuan sepihak, tetapi aktanya masih bersifat partai yaitu tidak lain persetujuan antara pihak debitur dan kreditur yang sama-sama datang menghadap didepan notaris, dan disana mereka saling mengikatkan diri didalam grosse akta pengakuan hutang dimaksud. Juga apabila nantinya dari grosse akta pengakuan hutang tersebut lahir grosse akta pengakuan hipotik (sertifikat hak tanggungan) maka grosse akta tersebut tidak dapat disebut grosse akta karena dokumen yang menjadi sandarannya didasarkan atas Grosse Akta pengakuan hutang.

Walaupun grosse akta pengakuan hutangnya tidak menurut ketentuan hukum (bukan pernyataan sepihak dari debitur) sebab dokumen yang menjadi sandaran kelahiran grosse akta hipotik bukan grosse akta pengakuan hutang, tetapi grosse akta notaris kuasa memasang hipotik, grosse akta hipotik dilahirkan dengan cara pihak debitur dan pihak kreditur sama-sama mengahadap PPAT membuat grosse akta hipotik. Didalam Pasal 
$224 \mathrm{HIR} / 258 \mathrm{Rbg}$ melarang menerapkan kedua bentuk grosse akta itu sekaligus bersamaan terhadap obyek kredit yang sama pada saat yang bersamaan. Adapun yang diperkenankan hukum adalah harus tegas memilih salah satu bentuk dalam pemanfaatan dan penerapannya.

Didalam kajian secara teoritis memang nampaknya grosse akta pengakuan hutang merupakan suatu jalan pintas yang cepat dan murah didalam mengatasi piutang yang macet. Masalah grosse akta tidaklah semudah seperti yang ada dalam teori, sebab dalam prakteknya masih banyak permasalahan yang dapat menghambat jalannya eksekusi tersebut. Bagi kreditur apabila telah berbagai usaha dilakukan untuk menyelesaikan pelunasan hutang yang macet dan ternyata Grosse Akta pengakuan hutang yang dimintakan penetapan eksekusi ke Pengadilan tidak berhsil, maka langkah kreditur yang harus diambil guna memenuhi pembayaran hutang dari debitur harus melalui gugatan biasa ke Pengadilan Negeri.

Dapatlah dikonklusikan bahwa prosedur penyelesaian kredit macet melalui gugatan perdata dimuka Pengadilan Negeri memerlukan waktu yang cukup lama, dan dalam prakteknya didalam proses peradilan belum sesuai dengan harapan kita. Demi mempercepat proses kreditur didalam gugatannya, suatu solusinya adalah kreditur dapat meminta "putusan dapat dilaksanakan terlebih dahulu" (uitvoerbaar bij vooraad). Putusan yang dapat dilaksanakan terlebih dahulu diatur dalam Pasal 180 ayat 1 dan Pasal 191 ayat $1 \mathrm{Rbg}^{10}$ yang mengatur persoalan yang sama dengan persyaratanpersyaratan yang sangat ketat antara lain ada syarat autentik atau tulisan dibawah tangan menurut Undang-Undang mempunyai kekuatan bukti, ada keputusan yang sudah memperoleh kekuatan yang pasti ada gugatan provisional yang dikabulkan, dan dalam sengketa mengenai perselisihan hak milik. Mengingat grosse akta pengakuan hutang adalah salah satu alat bukti yang autentik, artinya grosse akta a tersebut dapat digunakan sebagai alat bukti yang sempurna. Karenanya Grosse Akta pengakuan hutang yang dalam proses pengajuan gugatan, dapat disertakan permintaan uitvoerbaar bij vooraad. Pelaksanaan putusan lebih dahulu atau uitvoer baar bij vooraad, merupakan salah satu pengecualian terhadap prinsip azas bahwa eksekusi hanya dapat dijalankan terhadap putusan yang berkekuatan hukum tetap, yang artinya sekalipun terhadap putusan itu pihak tergugat mengajukan banding atau kasasi putusan dapat dijalankan eksekusinya lebih dulu.

Dalam kaitan dengan itu, apakah uitvoer baar bij vooraad tersebut sudah dapat menjamin terlaksananya suatu putusan yang diinginkan oleh

10 Yulianto. Tanggung Jawab Notaris Dalam Membuat Akta Jaminan Kredit Perbankan. (Surabaya, Mitra Media, 2012), hal. 65. 
penggugat? Karena berdasarkan S.E.M.A No. 03/ 1978 Tanggal 1 April 1978 bahwa hakim Pengadilan Negeri dalam waktu dua minggu setelah keputusan diucapkan maka Pengadilan Negeri harus mengirim salinan keputusan kepada Pengadilan Tinggi dan tembusannya kepada Mahkamah Agung. Tujuan utama interuksi dari Mahkamah Agung itu adalah: ${ }^{11}$

1 Memberi peringatan kepada semua hakim, terutama hakim pada tingkat pertama dan tingkat banding, agar sangat berhati-hati dan cermat menjatuhkan putusan eksekusi terlebih dahulu.

2 Memberi kewenangan kepada Pengadilan Tinggi dan Mahkamah Agung untuk mencampuri putusan eksekusi terlebih dahulu, berupa kewenangan untuk memerintahkan "penundaan"eksekusi terlebih dahulu yang dijatuhkan Pengadilan Negeri.

3 Oleh karena itu sebagai tindakan pengawasandan koreksi sebelum Pengadilan Negeri hendak menjalankan putusan eksekusi terlebih dahulu, harus minta izin persetujuan dulu dari Ketua Pengadilan Tinggi atau Mahkamah Agung.

Menurut Lubbers ${ }^{12}$ "notare at cavere" yang diterjemahkan sebagai catat dan jaga artinya mencatat saja tidak cukup, harus difikir juga bahwa akta itu harus berguna dikemudian hari jika terjadi keadaan khas. Tanggung jawab notaris tidak hanya terbatas pada kebenaran lahiriah dan formil akan tetapi notaris dituntut juga atas kebenaran secara materiil. Dahulu memang dianut pendapat bahwa dengan kekuatan pembuktian lahiriah dan formal tadi habislah pembuktian dari akta autentik.

\section{Kewenangan Hakim Menilai Grosse Akta}

Kewenangan hakim pada Pengadilan Negeri menjalankan grosse akta yang disebut dalam Pasal $224 \mathrm{HIR} / 258 \mathrm{Rbg}$, yakni: ${ }^{13}$

a. Nilai kekuatan grosse akta sama dengan putusan hakim yang telah memperoleh kekuatan hukum yang tetap, dengan demikian setiap grosse akta dengan sendirinya menurut hukum dapat langsung dijalankan eksekusinya.

b. Pada waktu debitur tidak memenuhi Grosse Akta dan pihak kreditur mengajukan permintaan eksekusi kepada Pengadilan Negeri, Ketua Pengadilan Negeri harus memerintahkan pelaksanaan eksekusinya.

c. Ketua Pengadilan Negeri memimpin jalannya perintah eksekusi yang dikeluarkannya.

11 Victor Sitomorang dan Sitanggang Cornentya. Grosse Akta Dalam Pembuktian Dan Eksekusi, Cetakan Pertama. (Jakarta: Renika Cipta, 1993), hal. 32.

12 M.Yahya Harahap. Op.Cit, hal. 86.

13 Iskandar. Hukum Acara Perdata Dalam Teori Dan Praktek, Cetakan VIII. (Bandung: Mandarmaju: 1997), hal. 34. 
d. Eksekusi grosse akta hanya dapat dihindari dengan jalan debitur menjalankan sendiri dengan sukarela atau terjadi "perdamaian" antara pihak debitur dengan pihak kreditur.

Pihak kreditur tidak boleh berkecil hati jika Pengadilan Negeri atau Badan Perdailan: Mahkamah Agung atau Ketua Pengadilan Tinggi menilai sah atau tidaknya suatu grosse akta. Sepanjang penilaian yang dilakukan tidak melampaui kewenangan yang dibenarkan hukum. Pengadilan Negeri dalam hal ini menilai grosse akta pengakuan hutang antara lain: ${ }^{14}$

a. Grosse akta pengakuan hutang harus murni berdiri sendiri, agar dia sah sebagai Grosse Akta yang berkekuatan eksekutorial. Berkaitan dengan penilaian inilah bahwa grosse akta pengakuan hutang tidak murni berdiri sendiri, yang artinya bahwa grosse akta pengakuan hutang tersebut telah dicampuraduk dengan syarat- syarat grosse akta hipotik dan peletakan jaminan. Terhadap hal ini, hakim Pengadilan Negeri menilai bahwa grosse akta tersebut mengandung cacat yuridis, sehingga dapat dinyatakan bahwa Grosse Akta tersebut tidak dapat dieksekusi sehingga didalam pemenuhan pembayarannya hanya dimintakan melalui proses gugat biasa.

b. Dalam menentukan sah atau tidaknya suatu perikatan grosse akta harus terlebih dahulu ditelusuri keabsahan perjanjian pokonya. Memang diakui, bahwa terkadang tidak mudah menilai sah atau tidaknya persetujuan berdasarkan ketentuan Pasal 1320 BW. Misalnya, untuk menentukan atau menilai apakah terkandung dalam suatu persetujuan unsur kekhilafan (dwalling), atau paksaan (dwang), atau penipuan (bedrog), tidak dapat dinilai diluar persidangan peradilan tetapi untuk menyatakan itu, dalam suatu persetujuan harus melalui putusan Pengadilan.

\section{KESIMPULAN}

Dalam sebuah grosse akta akan memiliki kekuatan hukum eksekutorial apabila dalam pembuatan akta harus diperhatikan syaratsyaratnya, baik itu syarat formil maupun syarat materiil. Serta grosse akta tersebut harus murni berdiri sendiri, yang artinya bahwa grosse akta tersebut tidak dicampuraduk dengan perjanjian lainnya. Grosse akta harus terlebih dahulu meminta fiat putusan pengadilan negeri, bertujuan untuk menilai adanya cacat yuridis pada suatu akta tersebut atau tidak, dan apabila ada hakim dalam pemeriksaannya menemukan cacat yuridis dalam isi perjanjiannya maka grosse akta tersebut untuk pelaksanan eksekusinya harus melalui gugatan perdata biasa.

14 Ibid 


\section{DAFTAR PUSTAKA}

\section{Buku}

Febby M. Sukatendel. 2009. Panduan Bantuan Hukum di Indonesia:Pedoman anda Memahani dan Menyelesaikan Masalah Hukum (Kerdit dan Masalah Keuangan). Jakarta: YLBHI.

Hilman Hadikusumo, 1995, Metode Pembuatan Kertas Kerja/Skripsi Ilmu Hukum, Bandung: Mandar Maju

Mariam Badrulzaman. 2004. Serial Hukum Perdata Kompilasi Hukum Jaminan, Buku II. Jakarta: Mandar Maju.

M. Yahyah Harahap. 1993. Perlawanan Terhadap Eksekusi Grosse Akta Serta Putusan Pengadilan dan Arbitrase dan Standar Hukum Eksekusi. Bandung: Citra Aditya Bakti.

Iskandar. 1997. Hukum Acara Perdata Dalam Teori Dan Praktek, Cetakan VIII. Mandarmaju: Bandung.

Soerjono Sokanto dan Sri Mamjudji, 2001k Penelitian Hukum NOrmatf (Suatu Tinjauan Singkat), Jakarta. Rajawali Press.

Victor Sitomorang dan Sitanggang Cornentya. 1993. Grosse Akta Dalam Pembuktian Dan Eksekusi, Cetakan Pertama. Renika Cipta: Jakarta.

Yulianto. 2012, Tanggung Jawab Notaris Dalam Membuat Akta Jaminan Kredit Perbankan. Surabaya: Mitra Media.

\section{Peraturan Perundang-undangan :}

Undang-Undang Republik Indonesia Nomor 2 tahun 2014 tentang Jabatan Notaris;

Kitab Undang-Undang Hukum Perdata (KUH Perdata);

H.I.R (Herzien Inlandsch Reglement)/Reglemen Indonesia yang Diperbaharui (R.I.B.)

Undang-Undang Republik Indonesia Nomor 2 Tahun 2014 tentang Perubahan Atas Undang-undang Nomor 30 Tahun 2004 Tentang Jabatan Notaris (UUJN).

Undang-Undang Republik Indonesia Nomor 48 Tahun 2009 Tentang Kekuasaan Kehakiman

Perda DIY No. 1/1955 tentang Perubahan Salinan Pertama (Grosse) Credietverband

\section{Jurnal dan Tesis}

Nia Mardianto. 2012. "Peranan Grosse Akta Pengakuan Hutang dalam Eksekusi Jaminan Kredit Harta Kekayaan”. Program Studi Ilmu Hukum Universitas Pembangunan Nasional "Veteran" Jawa Timur. 
Soetarno Sudja, 1988, "Grosse Akte Pengakuan Hutang dan Grosse Akte Hipotek", Jurnal Hukum dan Pembangunan (JHP) No. 6 tahun xviii. Shendy Vianni Rangian. 2015. "Pelaksanaan Eksekusi Grosse Akta Pengakuan Hutang Dalam Penyelesaian Sengketa Kredit Macet Perbankan”. Jurnal Calyptra. Vol. 4 Nomor 1. Surabaya: Fakultas Magister Kenotariatan Universitas Surabaya.

Yulita veni momuat, 2017. Tesis, Eksekusi Hak Tanggungan Berdasarkan Kekuatan Eksekutorial Pada Sertipikat Hak Tanggungan, Universitas Diponegoro 